\title{
Vertical migration of phytoplankton in coastal waters with different UVR transparency
}

\author{
Sabine Ulrike Gerbersdorf ${ }^{1 *}$ and Hendrik Schubert ${ }^{2}$
}

\begin{abstract}
Background: The vertical migration of phytoplankton was investigated in natural waters using in situ fluorescence profiling, chlorophyll a concentrations and life counts at two study sites differing in coloured dissolved organic matter (CDOM) concentrations. The data from the corresponding water depths (50-cm intervals down to $10 \mathrm{~m}$ ) and times (hourly, before dawn to sunset, several days) were related to the highly resolved $(2 \mathrm{~nm})$ underwater ultraviolet radiation (UVR)/photosynthetic active radiation (PAR) transparency (290 to $700 \mathrm{~nm}$ ).

Results: Chlorophyll a maxima of mainly motile dinoflagellates were observed in situ at all days and at both study sites (open marine, brackish waters), independent on prevailing weather conditions or CDOM concentrations. Phytoplankton migration was triggered solely by irradiance in the 400- to $700-\mathrm{nm}$ wavelength range (PAR) at the particular water depth, irrespective of PAR/UVR ratios and surface UVR (290 to $400 \mathrm{~nm}$ ), after an illumination period of about $40 \mathrm{~min}$. Interestingly, the PAR tolerance levels of the phytoplankton, which have been lower in CDOM-rich waters, matched their light acclimation values determined by parallel PAM measurements.
\end{abstract}

Conclusions: The response of the phytoplankton to PAR is not a sufficient protection strategy versus increasing UVR levels, which might have wide ecological implications beyond the level of primary producers to impact important ecosystem functions such as the delicate trophic interactions.

Keywords: phytoplankton, vertical migration, UV radiation, PAR, CDOM, underwater light spectrum.

\section{Background}

Over the last decades, there have been increasing reports on the depletion of the stratospheric ozone layer (reviewed in [1]). At first, the thinning ozone layer and ozone holes have been mainly associated with polar regions [2], yet this has been observed in the northern hemisphere too [3-5]. Although the transmission of ultraviolet radiation (UVR) is highly variable due to e.g. solar variability or meteorological conditions, climate change is expected to enhance UVR, consisting of UVA (320 to $400 \mathrm{~nm}$ ) and UVB (290 to $320 \mathrm{~nm}$ ), in the long run $[6,7]$. These reports initiated numerous investigations on possible effects of UV radiation on terrestric and aquatic (marine and freshwater) organisms. In the pelagic zone, an elevated sensitivity of phytoplankton and zooplankton versus UVR could be observed with

\footnotetext{
* Correspondence: Sabine.Gerbersdorf@iws.uni-stuttgart.de

'Institute of Hydraulic Engineering, Hydraulic Laboratory, Pfaffenwaldring 61, University of Stuttgart, 70569 Stuttgart, Germany

Full list of author information is available at the end of the article
}

effects on growth, production, cell biochemistry, ontogeny, genome and mortality (reviewed in [8-10]).

Beyond the UVR effects on single organisms, the ecosystem functions of the aquatic habitats may be threatened considering for instance the delicate balance of trophic interactions [11]. The UVR-induced morphological, biochemical and community changes in phytoplankton decrease the food quality and quantity to the zooplankton with further implications on their food ingestion and digestion [12-14]. To maximise their secondary production, zooplankton is known to correlate their vertical movements to the phytoplankton over certain periods of the day [15]. Differences in the sensitivity to UV radiation in phytoplankton and zooplankton may result in varying non-synchronic pattern of vertical migration which could lead to a de-coupling of the food chain at this early level [16-18]. Provided, the zooplankton follows the movements of the phytoplankton, the grazers may be increasingly exposed to unfavourable conditions such as increased UVR or predators $[19,20]$. Altogether, the UV radiation can directly or indirectly

\section{实 Springer}

(C) 2011 Gerbersdorf and Schubert; licensee Springer. This is an Open Access article distributed under the terms of the Creative Commons Attribution License (http://creativecommons.org/licenses/by/2.0), which permits unrestricted use, distribution, and reproduction in any medium, provided the original work is properly cited. 
influence the phytoplankton-zooplankton interactions with severe cumulative effects up to higher trophic levels in the pelagic foodweb.

Most studies about enhanced UV radiation and phytoplankton concern the effects on single cells as well as on primary production and community changes tested in the laboratory (e.g. $[21,22])$. Vertical migration of phytoplankton as a response to PAR or UVR has been mainly examined in laboratory setups/mesocosm (e.g. [23]). Little is published about vertical movements of phytoplankton in their aquatic habitat under environmentally relevant underwater light conditions in general and UVR transparency in particular. The present paper investigates the in situ response of marine phytoplankton to natural scenarios of different UVR as well as varying UVR/PAR ratios with the hypothesis that UVR triggers the vertical migration of the motile pelagic autotrophs. Over the course of several days, the vertical distribution of chlorophyll as a proxy for phytoplankton biomass was determined by "Backscat" in situ fluorometer. The fluorescence signals were calibrated repeatedly by chlorophyll concentrations determined photometrically in the corresponding water samples, accompanied by life counts of phytoplankton. These data were related to the prevailing irradiances and doses of PAR and UVR, measured in high resolution by a spectroradiometer, within the particular water depths. Since the penetration of PAR and UVR into the water body depends, inter alia, strongly on the concentrations of coloured dissolved organic matter (cDOM; e.g. [24,25]), investigations were carried out at two coastal study sites that differed significantly in water transparency: the open marine waters (Helgoland, North Sea) as opposed to the near-shore brackish waters (Hiddensee, Baltic Sea).

\section{Results}

\section{Calibration of the in situ fluorometer}

Cell counting or classical chlorophyll extraction procedures are time consuming and labour intensive. In order to ensure sufficient profile resolution and repetition frequency, the use of an in situ fluorometer has been chosen instead. Relying on in vivo fluorescence, these instruments are sensitive to all kinds of adaptations (varying results due to shifts in community composition) and acclimations (varying values due to an increase of non-photochemical quenching (NPQ) after overexcitation) to influence the quantum yield of chlorophyll $a$. Thus, a careful and accurate calibration to the prevailing chlorophyll concentrations is crucial which has to be monitored regularly over the experimental period. Various calibration runs of the in situ fluorometer at both study sites (Figure 1 shows two examples) visualised the degree of adaptation of the measured data to the model.
Different instruments have been used and the absolute chlorophyll values varied at the two study sites, resulting in different slopes of the calibration curves (Figure 1). However, both calibration curves show a good correlation between fluorescence signal and chlorophyll $a$ concentration $\left(\mathrm{A}, R^{2}=0.77 ; \mathrm{B}, R^{2}=0.89\right.$; both correlations significant at $p<0.01)$. Deviation of the measured points from the ideal calibration curve showed no correlation to sampling depth or time (data not shown) which could indicate an influence of NPQ or phytoplankton composition.

\section{The underwater light field}

Figure 2 allows a comparison of the attenuation characteristics at the open marine waters of Helgoland (North Sea) and the near-shore waters of Hiddensee (Baltic Sea). High attenuation values in the short wavelength range indicate that both water bodies belong to the "coastal type" of water types Jerlov's classification [26]. With a transmission maximum of more than $70 \%$ around 550 $\mathrm{nm}$, the spectrum shown for Helgoland was a typical example of the prevailing optical properties in the water column over the time of the campaign. The spectrum indicated a coastal type 3 with - for coastal types - medium cDOM concentration up to $1.2 \mathrm{mg} \mathrm{L}^{-1}$ [27] (Figure 2). Maximum variations of the attenuation values were $5.4 \%$ at $315 \mathrm{~nm}$. The 1\% depth for PAR (400 to $700 \mathrm{~nm}$ ), UVA ( 320 to $400 \mathrm{~nm}$ ) and UVB (280 to $320 \mathrm{~nm}$ ) were calculated as $8.20,3.10$ and $1.24 \mathrm{~m}$, respectively.

With a transmission maximum of $52 \%$ around $550 \mathrm{~nm}$ (spectrum measured in autumn campaign, October, shown in Figure 2), the water body at Hiddensee could be classified as coastal type 9; extremely strong short wavelength attenuation confirmed the reported high cDOM concentrations (typically up to $4 \mathrm{mg} \mathrm{L}^{-1}[27]$ ) within this region [28]. Domin et al. [29] could show that the removal of tripton had little effect on the absorbance characteristics of the water bodies of the southern Baltic Sea; thus proofing the major influence of cDOM in this region. The calculated $1 \%$ depth for PAR, UVA and UVB were 6.0, 1.2 and $0.4 \mathrm{~m}$, respectively.

Table 1 gives an overview about the irradiance conditions during both campaigns. The actual daily integrated PAR irradiances were always lower than the theoretical maximum (75 mol photons $\mathrm{m}^{-2}$ day $^{-1}$ for 1 May and 41 mol photons $\mathrm{m}^{-2}$ day $^{-1}$ for 1 October; both values calculated by solar elevation, assuming ideal atmospheric conditions [30]). This indicated that at none of the campaign days fully clear sky conditions and high atmospheric transparency prevailed. Yet, on days such as the 28 September and the 29 April, long periods of cloudless sky resulted in high PAR/UVR ratios; conditions being regarded as an optimum for observations on phytoplankton migration. Other days such as the 5 October 

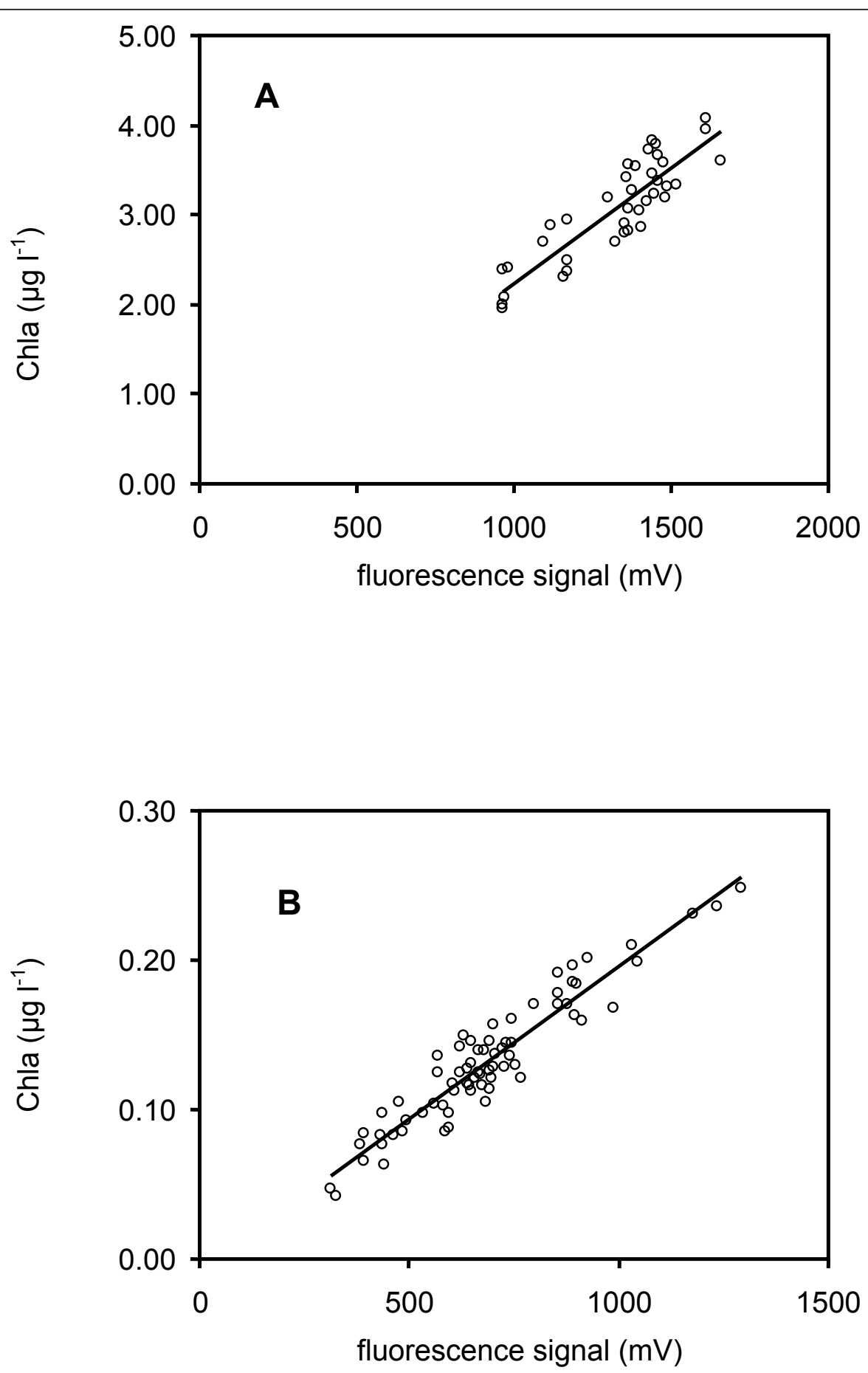

Figure 1 Calibration of the in vivo chlorophyll fluorometer, Fluorescence signals (millivolts) plotted versus the chlorophyll $a$ concentrations $(\mathrm{Chl} a)$, determined in situ and in water samples, respectively, within corresponding water depths at Hiddensee (A) and Helgoland (B). All data of vertical, spatial and temporal variations determined over the whole field campaigns are included.

and the 1 May resulted in low PAR values shifting the PAR/UVR ratios to very low values. Still, this broad variety of weather conditions as visualised by the range of PAR/UVR ratios, allowed for insights in the responses of phytoplankton to different light scenarios.
Vertical movement of phytoplankton in the water column Microscopic evaluation revealed that the phytoplankton at the Helgoland Harbour was clearly dominated by motile species in the late spring and consisted mainly of dinoflagellates (between 25\% and 46\%) and 


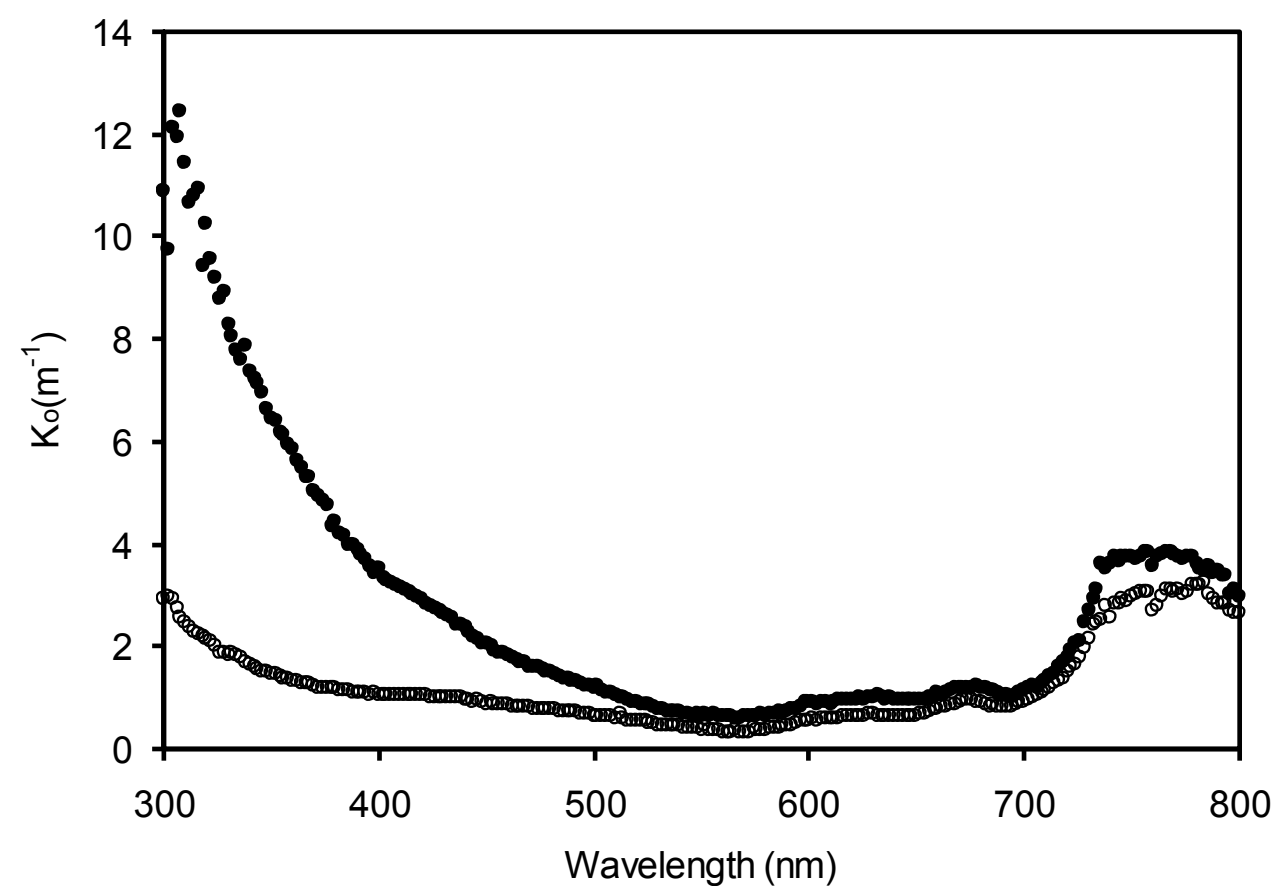

Figure 2 Attenuation spectra ( $\boldsymbol{K}_{\mathbf{o}}=$ overall attenuation coefficient). Attenuation spectra within water bodies of Helgoland (open circles) and Hiddensee (filled circles) calculated from five successive scans measured at intervals of 5 to $50 \mathrm{~cm}$.

Raphidiophyta ( = Chloromonads, between $54 \%$ and 75\%). Typical species that partially dominated the phytoplankton were Gyrodinium (small to large $<5$ to 200 $\mu \mathrm{m}$, unarmored dinoflagellate forming large blooms and

Table 1 Temperature, salinity and daily doses of UVB, UVA and PAR as well as their ratios

\begin{tabular}{|c|c|c|c|c|c|c|c|}
\hline Date & Temperature & Salinity & UVB & UVA & PAR & $\begin{array}{l}\text { PAR/ } \\
\text { UVB }\end{array}$ & $\begin{array}{l}\text { PAR/ } \\
\text { UVA }\end{array}$ \\
\hline $\begin{array}{l}28 \text { Sep } \\
1999\end{array}$ & 15 & 7.6 & 0.13 & 2.63 & 27 & 205 & 10 \\
\hline $\begin{array}{l}29 \text { Sep } \\
1999\end{array}$ & 14.8 & 7.7 & 0.10 & 1.90 & 21 & 209 & 11 \\
\hline $\begin{array}{l}05 \text { Oct } \\
1999\end{array}$ & 14 & 8.0 & 0.05 & 1.16 & 11 & 197 & 9 \\
\hline $\begin{array}{l}06 \text { Oct } \\
1999\end{array}$ & 13.6 & 7.9 & 0.08 & 1.75 & 18 & 210 & 10 \\
\hline $\begin{array}{l}27 \mathrm{Apr} \\
2000\end{array}$ & 8.0 & 33.1 & 0.17 & 3.17 & 37 & 219 & 12 \\
\hline $\begin{array}{l}29 \mathrm{Apr} \\
2000\end{array}$ & 9.0 & 32.3 & 0.17 & 3.22 & 39 & 227 & 12 \\
\hline $\begin{array}{l}01 \text { May } \\
2000\end{array}$ & 10.2 & 31.8 & 0.11 & 1.90 & 20 & 177 & 11 \\
\hline $\begin{array}{l}03 \text { May } \\
2000\end{array}$ & 10.7 & 31.9 & 0.17 & 3.01 & 35 & 211 & 12 \\
\hline
\end{tabular}

Temperature $\left({ }^{\circ} \mathrm{C}\right)$, salinity (psu) and daily doses (moles of photons per metre squared per day) of UVB ( 280 to $320 \mathrm{~nm}$ ), UVA (320 to $400 \mathrm{~nm}$ ) and PAR (400 to $700 \mathrm{~nm}$ ) as well as their ratios; including the data of all sampling days at Hiddensee (autumn campaign, September to October) and Helgoland (spring campaign, April to May). Numbers in italics indicate the use of data from the nearby coastal station Zingst (30 km). producing toxins of economic importance) and Fibrocapsa (small, flagellated golden brown cells, capable of producing toxins killing fish and seals). The autumn aspect of the phytoplankton composition in the nearshore region northeast of the island Hiddensee showed a vast majority of dinoflagellates (between $38 \%$ and $82 \%$, e.g. Dinophysis, Prorocentrum) confirming the trend that dinoflagellates have been increasing proportionally in coastal waters in recent decades. As well, typical planktonic species of an autumn diatom bloom (e.g. Chaetocerus, Coscinodiscus) have been determined (data not shown).

In Figure 3, one typical example of the daily course of vertical chlorophyll $a$ distribution in the water column of the Helgoland Harbour is shown for the spring campaign. In the early morning as well as in the late evening, chlorophyll $a$ was almost equally distributed over the whole water column. In contrast, around noon, a clear maximum of chlorophyll $a$ developed in the water column; a phenomenon that could be observed at least periodically at all days, including the ones with unfavourable weather conditions and at both study sites. The fact that all of the determined maxima appeared at intermediate depths proves that it is not caused by NPQ. Moreover, between morning and noon time, the highest abundance peak of dinoflagellates shifted gradually from surface waters (49\%) to medium depths $(74 \%$ to $82 \%$ in 2 to $5 \mathrm{~m}$ depth) to coincide with the 
(A)

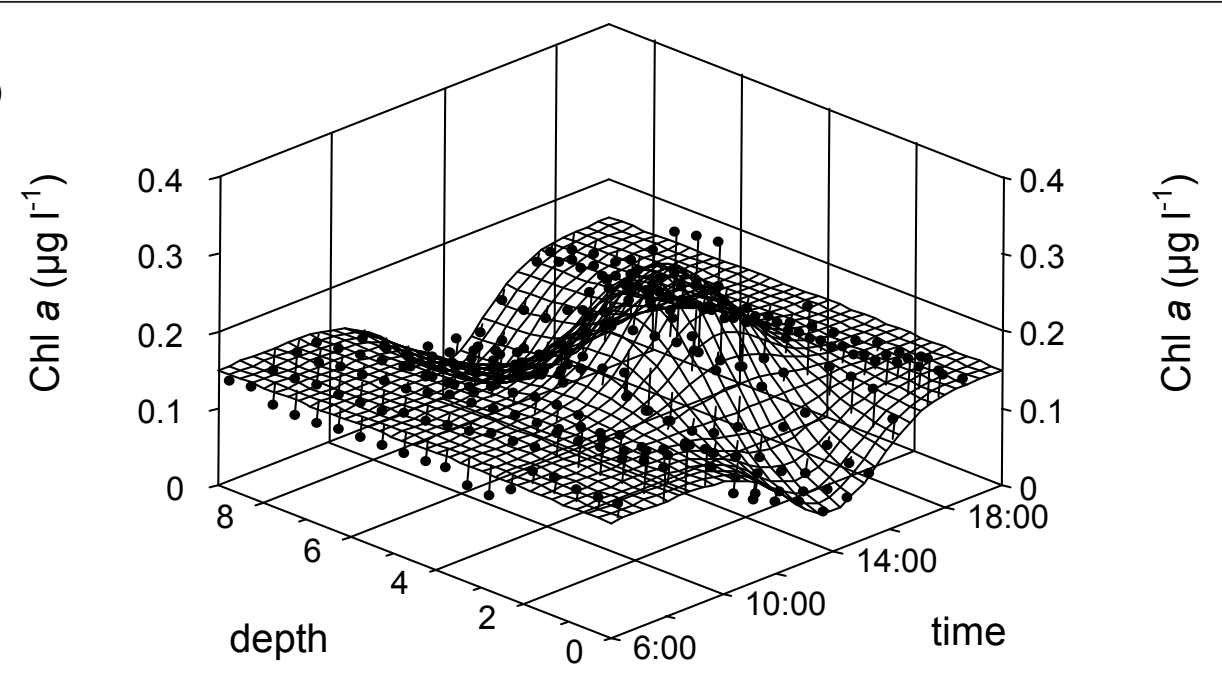

(B)

Chl a $\left(\mu \mathrm{g} \mathrm{I}^{-1}\right)$

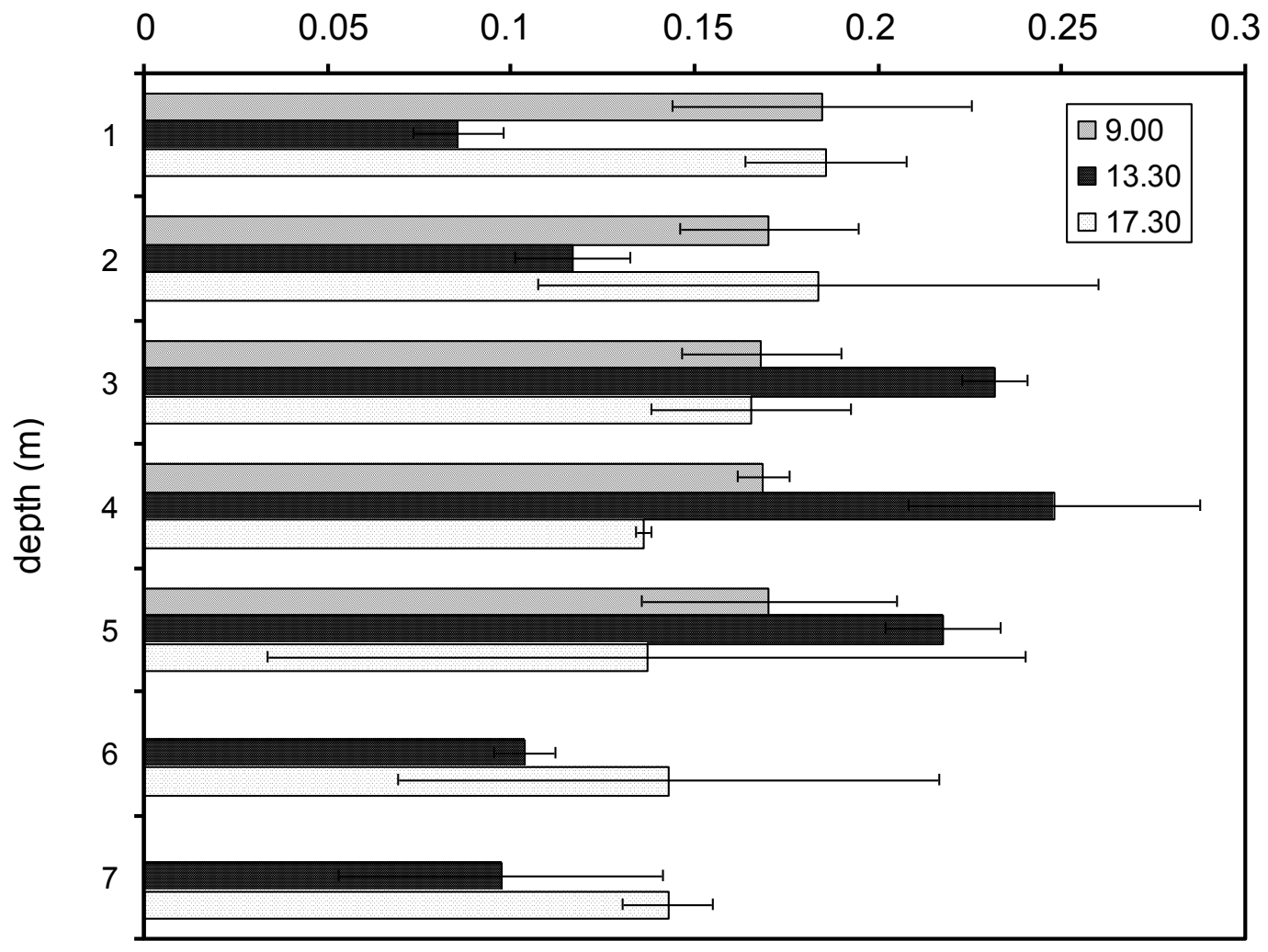

Figure 3 Vertical distribution of chlorophyll $a$ concentration in the water column at study site Helgoland. Shown are vertical chlorophyll a profiles during the second day of the spring campaign. (A) shows a surface grid calculated from fluorescence data by means of a Gaussian fit procedure using TC3D software (see M\&M). (B) shows Chl a concentration profiles determined by means of the DMF-extraction method taken the same day. Vertical bars denote standard deviation. 
chlorophyll maximum; as observed on day 4 with clear sky at Hiddensee.

A maximum of phytoplankton abundance was defined as a minimum of three subsequent layers/depths with Chlorophyll $a$ concentrations exceeding the average Chlorophyll $a$ concentration of the total vertical depth profile by more than 19\% for Helgoland and 9\% for Hiddensee measurements. The lower threshold for Hiddensee was at first chosen under the assumption that the higher trophic status at this water body [31] may result in shifts of the phytoplankton communities towards non-mobile species; as could be shown by Wasmund and Uhlig [32] as well as Sagert et al. [33] for the German Baltic Coast. In fact, the proportion of motile flagellates has been much higher for Helgoland waters as compared to Hiddensee. By definition, 32 out of a total of 54 profiles measured at Helgoland and 15 out of 31 profiles measured at Hiddensee showed a clear chlorophyll depth maximum which could be used for further evaluation of irradiance dependencies. As compared to Helgoland, relatively fewer profiles determined in Hiddensee offshore waters met the above outlined criteria, which can be explained by the wind conditions. Wind speed peaking at $14 \mathrm{~m} \mathrm{~s}^{-1}$ has led to intense Langmuircirculation at the first 2 days of the autumn campaign at the study site Hiddensee, while the wind speed was only less than $5.5 \mathrm{~m} \mathrm{~s}^{-1}$ on the other days. In contrast, the wind speed was lower than $5.5 \mathrm{~m}^{-1} \mathrm{~s}^{-1}$ during all field measurements at the Helgoland harbour.

With the information on the time and vertical location of the chlorophyll depth maximum, the next step was to estimate the response time of the phytoplankton - i.e. the period between sensing a trigger and forming a depth maximum. For this purpose, sub-surface irradiances (surface irradiances corrected for reflection) were integrated for different time intervals between 3 and $120 \mathrm{~min}$ before the occurrence of the chlorophyll depth maximum and plotted against the depths of corresponding chlorophyll $a$ maxima. Figure 4 shows the $R^{2}$ values for the different surface irradiance integration times with the best correlation determined by integrating the last $45 \mathrm{~min}$ before the chlorophyll depth maximum. Consequently, all further evaluations were carried out using an integration period of 45 min before the actual chlorophyll profile measurement.

Which spectral range is important for vertical migration? Since the surface irradiance differed by magnitudes over the days of the measurements, the accuracy of the data varied significantly too, which made a straightforward correlation of the different spectral ranges with the depth maxima difficult. Moreover, the formation of depth chlorophyll a maximum is likely to be a physiological response to the underwater light regime rather than to surface light conditions, which cannot be sensed by the organisms directly. For these reasons, the underwater light field at the particular depth of the chlorophyll $a$ maximum had to be calculated based on the continuous surface light measurements (summarised in Table 1) and the underwater attenuation spectra (Figure 2).

In Figures 5 and 6 (Helgoland and Hiddensee, respectively), the underwater irradiances/doses calculated at the chlorophyll $a$ maximum depth were plotted versus the surface irradiances/doses; thereby distinguishing between the different spectral ranges of UVR (A, B) and PAR (C). No relation could be determined between the calculated UVB doses at the chlorophyll $a$ maximum depth and the measured UVB part of the surface light (Figures 5A and 6A). At both study sites, highest UVB doses at the chlorophyll $a$ maximum depth coincided with lowest surface UVB values, where comparatively little action of the phytoplankton would have been necessary to escape to deeper regions. A similar picture could be seen for UVA radiation at both study sites (Figures $5 \mathrm{~B}$ and $6 \mathrm{~B}$ ). At Helgoland, the UVA doses at the chlorophyll $a$ maxima depth has been mostly around $0.2 \mathrm{~kJ} \mathrm{~m}^{-}$ ${ }^{2}$ under higher surface light conditions (Figure 5B). However, the overall picture was quite inhomogeneous and with increasing UVA doses up to almost $1 \mathrm{~kJ} \mathrm{~m}^{-2}$ (Figure 5B), there was evidently no maximum limit.

In contrast to UVR, a clear maximum PAR intensity was maintained by the relocation of the chlorophyll $a$ maximum depth at both study sites (Figures $5 \mathrm{C}$ and $6 \mathrm{C})$. Lower PAR intensities at the chlorophyll $a$ maximum depth reflected situations when the maximum PAR irradiance to be tolerated was not even exceeded in sub-surface layers. Interestingly, this maximum PAR irradiance was different at both study sites with values around 185 and $25 \mu \mathrm{mol}$ photons $\mathrm{m}^{-2} \mathrm{~s}^{-1}$ at Helgoland and Hiddensee, respectively.

Because these results suggested a relation between photosynthesis and preferred irradiance, the relative electron transport rate (rETR) has been determined during the second campaign at Helgoland (Figure 7). Absolute values of light affinity and maximum photosynthetic rate cannot be derived from these curves unless the cross-absorbance section of photosystem II (PSII) is known. However, it is valid to determine the $E_{\mathrm{k}}$ value (light saturation of photosynthesis) which is the quotient of $P_{\max }$ and alpha and thus independent of the absolute scale of the photosynthesis rate. In Figure 7, the calculated $E_{\mathrm{k}}$ value indicated light saturation at about 219 $\mu \mathrm{mol}$ photons $\mathrm{m}^{-2} \mathrm{~s}^{-1}$; a value close to the maximum PAR intensity $\left(185 \mu \mathrm{mol}\right.$ photons $\left.\mathrm{m}^{-2} \mathrm{~s}^{-1}\right)$ determined in situ at the chlorophyll $a$ maximum depth at Helgoland. 


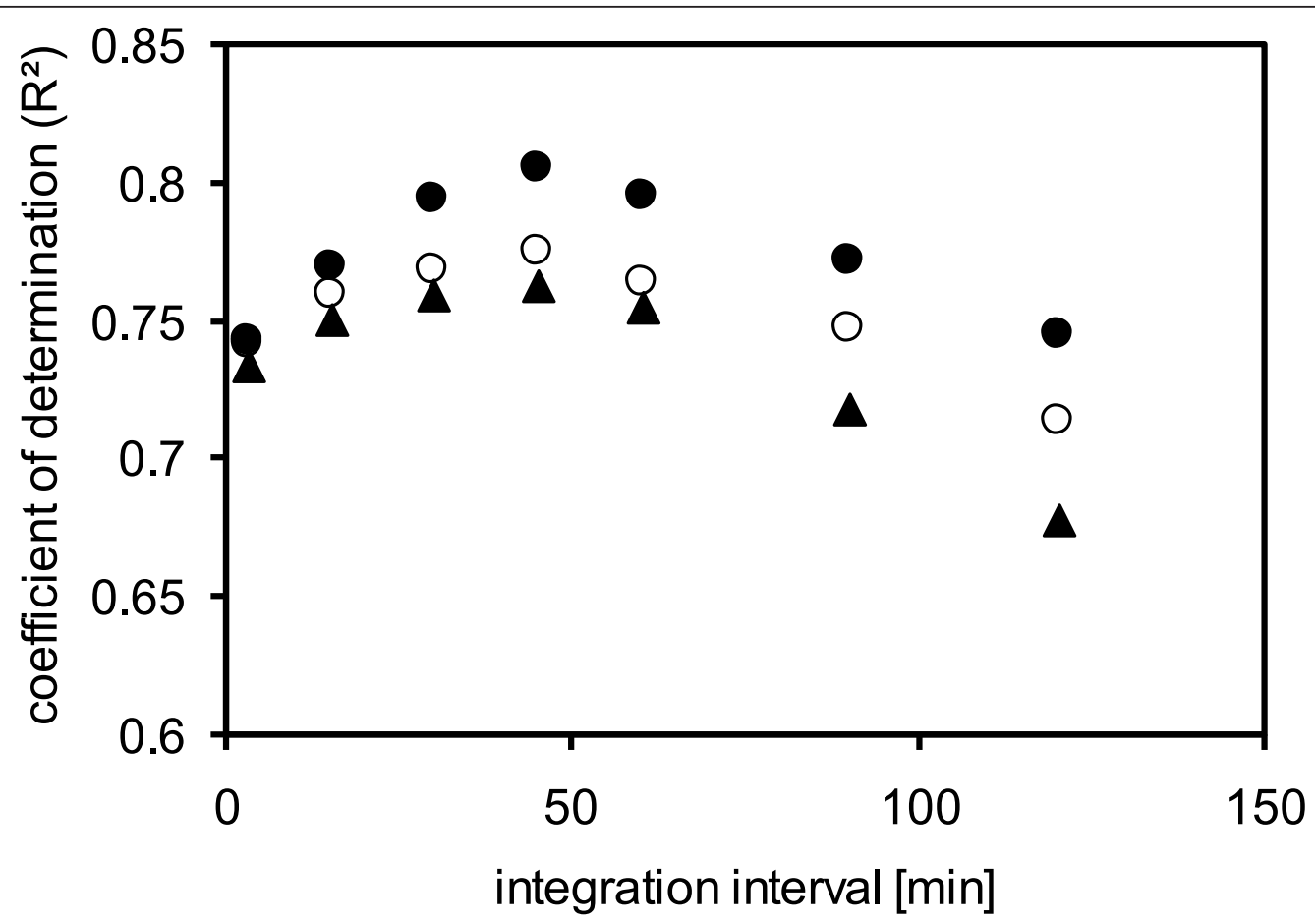

Figure 4 Coefficient of determination $\left(R^{2}\right)$ values of the linear regression. Shown are determination coefficient values between sub-surface irradiances/doses, calculated for different integration intervals, and chlorophyll a maximum depths. The different wavelength ranges of the subsurface irradiances/doses are represented by filled circles (PAR 400 to $700 \mathrm{~nm}$ ), open circles (UVA 320 to $400 \mathrm{~nm}$ ) and triangles (UVB 290 to 320 $\mathrm{nm})$.

\section{Discussion}

Solar radiation induced explicit vertical movements of the phytoplankton that were investigated in situ in the open coastal waters of Helgoland (North Sea) and the near-shore waters of Hiddensee (southern Baltic Sea). However, the part of the solar spectrum being most effective in triggering downward migration was calculated to be the PAR but not the UVR (UVA or UVA) wavelengths as hypothesised earlier.

\section{Reaction time and vertical movement in phytoplankton}

By integrating the surface photon flux/doses for the single wavelength regions (UVR, PAR) over different times and relating this to the chlorophyll maxima depths, it could be shown that an illumination period of about 45 min has been crucial for the subsequent development of the chlorophyll maxima. Thus, vertical migration of the phytoplankton must have been an immediate response to the increase in solar radiation. Although passive sinking may occur as flagella movement is inhibited by high irradiance of visible light [34] or UVR [35], the speed of downward movement in the present study is higher than explained by Stokes law. Moreover, as can be seen in Figure 3, chlorophyll depletion above and below the chlorophyll maximum depth occurs simultaneously and thus supports the concept of active swimming.
Swimming speed of chlorophytes and dinoflagellates has been documented to be in the range of 20 to $60 \mu \mathrm{m} \mathrm{s}^{-1}$ which would correspond to hourly movements over distances of about 7 to $22 \mathrm{~cm}$ [23]. At the time of sampling, dinophyta dominated within Helgoland (spring time) and Hiddensee (autumn time) waters; that is a typical phytoplankton composition at the particular times of the year for the open marine waters of Helgoland (e.g. [36,37]) and for the near-shore waters of Hiddensee (e.g. [38]). The quick development of chlorophyll $a$ maxima in the present paper suggests that these motile pelagic autotrophs managed even bigger distances in the short time available as to be expected by the laboratory experiments of Richter et al. (2007). Indeed, investigations from the natural environment have documented downward migrations of several metres in phytoplankton over the course of 1 day [39]. The discrepancies between laboratory measurements of swimming speed and field observations of rapidly changing chlorophyll $a$ maxima over several metres are probably due to the fact that the idea of an entire phytoplankton population migrating through the water column oversimplifies the natural conditions. As visualised in Figure 3, a substantial proportion of the chlorophyll remains evenly distributed in the water column; even under calm and sunny conditions that would be 
(A)

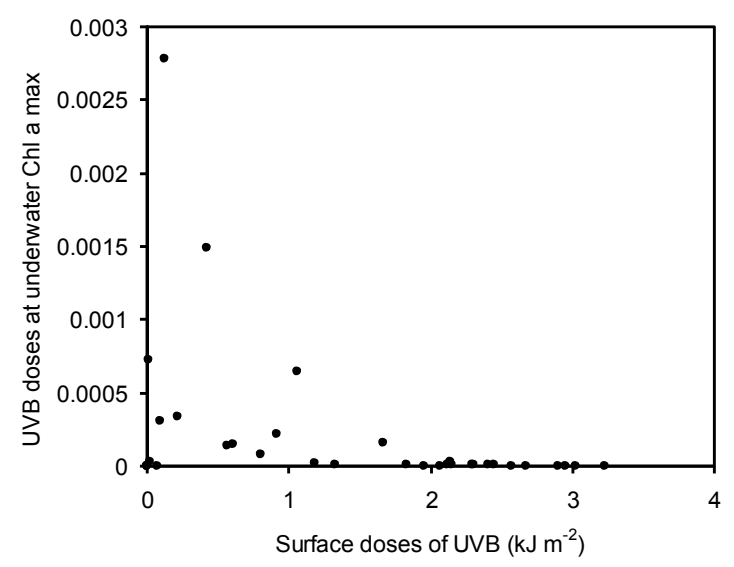

(B)

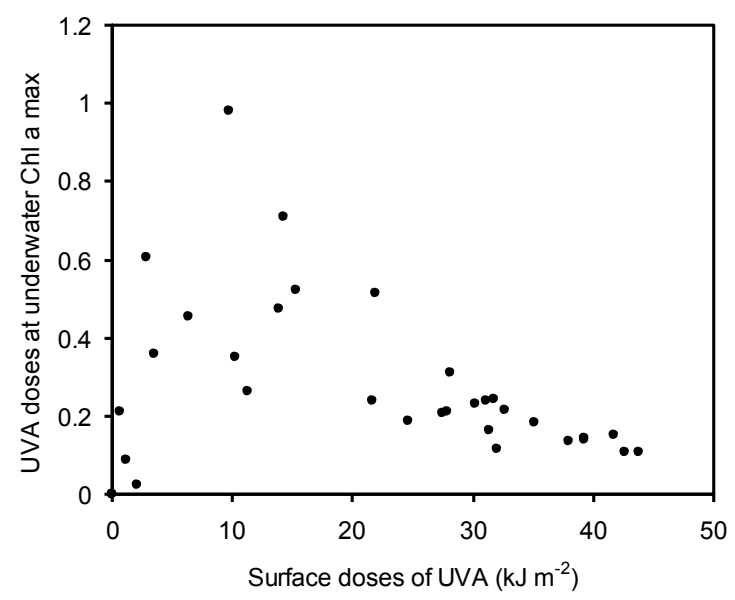

(C)

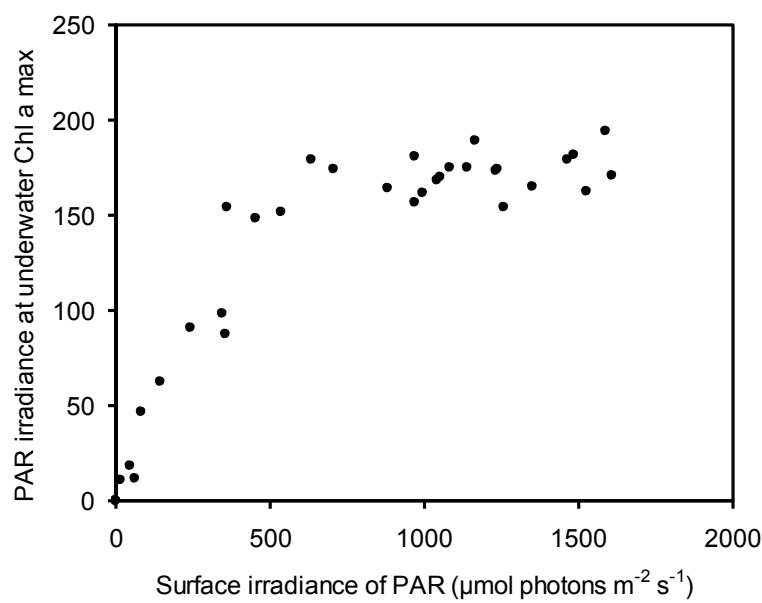

Figure 5 Surface irradiances/doses versus underwater irradiances/doses. Surface versus underwater irradiances/doses at the chlorophyll $a$ maximum depth (Chl a max.) at Helgoland for the different wavelength ranges UVB (A), UVA (B) and PAR (C) including all data from profiles with pronounced chlorophyll a maxima. Values at both axes are in the energetic unit kilojoules per metre squared for UVB (A) and UVA (B) and in the quantametric unit micromoles of photons per meter squared per second for PAR (C); calculations see M\&M. 
(A)

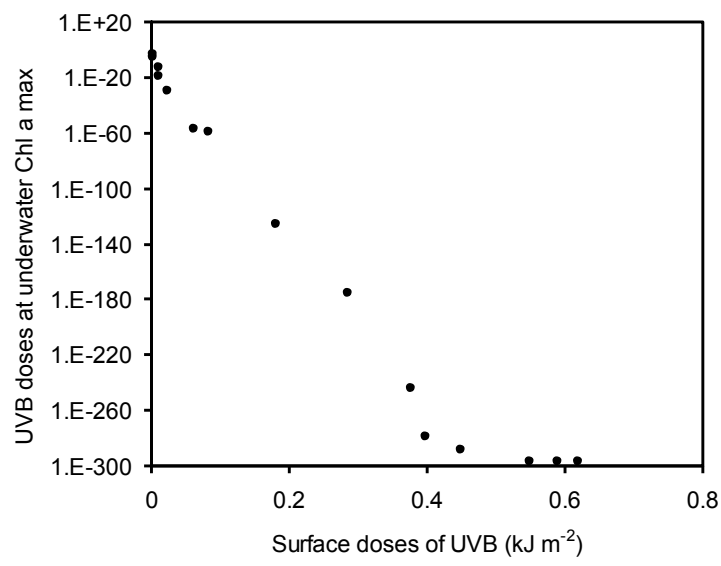

(B)

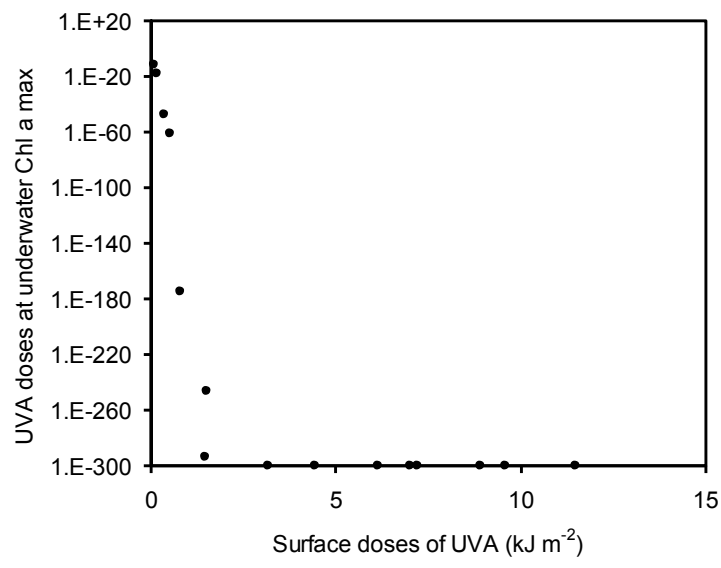

(C)

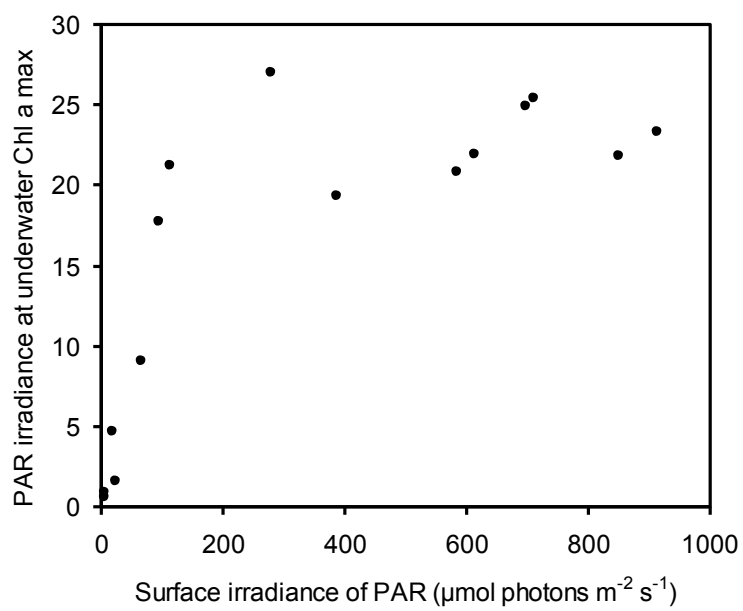

Figure 6 Surface irradiances/doses versus underwater irradiances/doses. Surface versus irradiances/doses at the chlorophyll a maximum depth (Chl a max.) at Hiddensee for the different wavelength ranges UVB (A), UVA (B) and PAR (C) including all data from profiles with

pronounced chlorophyll a maxima. Values at both axes are in the energetic unit kilojoules per metre squared for UVB (A) and UVA (B) and in the quantametric unit micromoles of photons per meter squared per second for PAR (C); calculations see M\&M. 


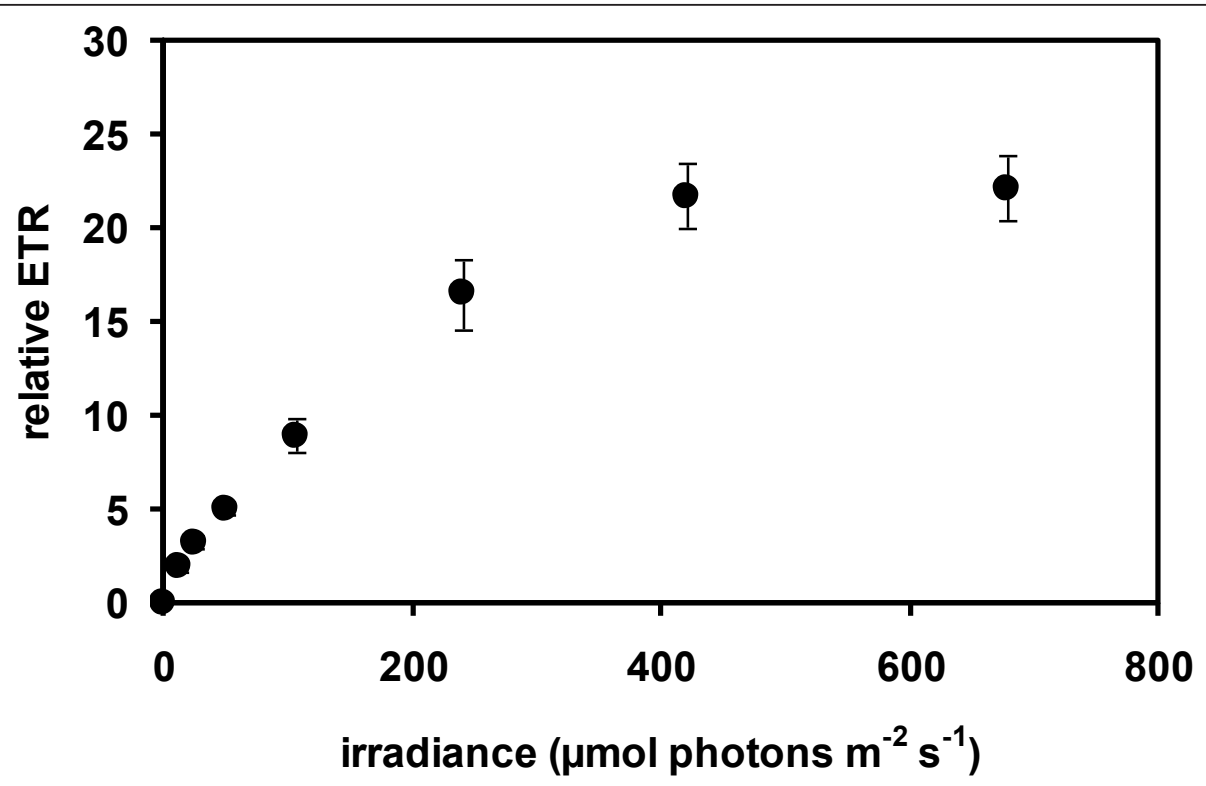

Figure 7 The rETR of phytoplankton. rETR of phytoplankton is plotted versus irradiance ( $n=3$ of the first 3 days of the spring campaign) determined in situ before sunrise (completed before 5:15 a.m.) at study site Helgoland. The light saturation of photosynthesis ( $E_{k}$, quotient of $P_{\max }$ and alpha) was calculated to be around $219 \mu \mathrm{mol}$ photons $\mathrm{m}^{-2} \mathrm{~s}^{-1}$.

preferable for vertical movement. Thus, the chlorophyll a maximum may rather illustrate an ongoing process where organisms below and above the "preferred irradiance" move towards the optimum light conditions; depleting, but not emptying the layers behind. In consequence, the single organism would not need to move over a distance of $1 \mathrm{~m}$ in $1 \mathrm{~h}$ to induce changes in phytoplankton distribution as observed here.

\section{The PAR range as the trigger for vertical migration}

The present study could show that vertical migration of the phytoplankton occurred even under average solar radiation conditions in situations of low wind speed. While the chlorophyll $a$ as a proxy for phytoplankton biomass was almost equally distributed in the early morning and late evening hours, a clear chlorophyll maximum developed around noon. This was reflected in the life counts of phytoplankton in the different water depths over the day, where the highest abundance of motile dinoflagellates coincided with the chlorophyll $a$ maximum. This maximum was not triggered by tidal movements because the shape did not change over the investigated days, whereas the tidal regime shifted approximately $6 \mathrm{~h}$.

Although vertical migration of phytoplankton triggered by light (and others such as gravity, magnetic field, chemical gradients, etc.) is a long-known phenomenon, there are few studies on the effects of the varying underwater light quantity and quality on phytoplankton movement $[23,35,40]$. It could be shown that light quality modulates vertical phytoplankton movement, but the empirical evidence as to which wavelength is responsible, was still lacking. In the present study, the phytoplankton reacted to the PAR rather than to the UVR range in solar radiation as was expected earlier. Since numerous investigations reported detrimental effects of increasing UV radiation on single cells and community composition of phytoplankton and zooplankton [12-14], it seemed logical to presume a UV avoidance mechanism in these organisms. Indeed, some zooplankton species are able to detect and escape UV radiation (e.g. [41]), which is in contrast to the phytoplankton reactions investigated here $i n s i t u$. This could be explained by the fact that most of the microalgal photoreceptors are not sensitive in the UVR range [17] although there is evidence that some receptors are able to absorb in the blue and UVR region (e.g. Euglena gracilis $[18,42])$.

\section{Water bodies of different radiation transparency}

The sensitivity of phytoplankton to PAR would imply that motile species evolved avoidance mechanisms in addition to acclimation mechanisms against the exposure of high irradiance. Since UVR levels are usually closely linked to PAR values, the phytoplankton reaction to PAR might as well protect against UVR exposure. However, the predicted increase in UVR/PAR ratio due to a continuous decrease in ozone [6,7] could change this in highly transparent water bodies. In coastal areas characterised by high concentrations of humic substances, an 
increased UVR/PAR ratio might be balanced by the preferential absorption of the coloured part of the dissolved organic matter (cDOM) [25] in the UVR range. Thus, one may predict that increasing UV radiation has fewer implications for phytoplankton in cDOM-rich coastal waters. On the other hand, the exposure to harmful photochemical intermediate products can induce stress reactions in phytoplankton. Moreover, phytoplankton from CDOM-rich waters could have an enhanced sensitivity to UVR stress that is attributed to a lack in preadaptation $[43,44]$. Only in the long run, the phytoplankton from coastal turbid waters will have a chance to adapt to increasing UVR exposure by e.g. shifts in species composition and physiology, with hitherto unknown consequences for its functionality and ecosystem services for the aquatic habitat.

In the present paper, the development and re-distribution of the chlorophyll $a$ maximum in response to solar radiation was not restricted to the water body of higher transparency like in Helgoland/North Sea (70\% transmission at $550 \mathrm{~nm}$ ). The same phenomenon could be observed in the CDOM-rich waters near shore of Hiddensee/southern Baltic Sea (52\% transmission at 550 $\mathrm{nm})$. At both study sites, the phytoplankton reacted to similar surface irradiances despite the different water transparencies. However, the maximum PAR intensity to be tolerated by the phytoplankton was strikingly different: about $180 \mu \mathrm{mol}$ photons $\mathrm{m}^{-2} \mathrm{~s}^{-1}$ at Helgoland and $25 \mu \mathrm{mol}$ photons $\mathrm{m}^{-2} \mathrm{~s}^{-1}$ at Hiddensee. For Helgoland, the light saturation of the phytoplankton was additionally determined via the relative electron transport rate and with $219 \mu \mathrm{mol}$ photons $\mathrm{m}^{-2} \mathrm{~s}^{-1}$, the value was very close to the maximum PAR intensity tolerated in situ. The shade acclimation of the Hiddensee phytoplankton is probably linked to the deep and continuous mixing of the water column the last 3 days before the first sampling. With prevailing wind speeds of more than $4 \mathrm{~m} \mathrm{~s}^{-1}$, a complete mixing of the water column has been observed before in these water bodies [45]. Along with the low PAR transparency, low light acclimation is likely to be the consequence. The data clearly confirmed the different light acclimation of phytoplankton from Helgoland and Hiddensee due to varying concentrations of $\mathrm{cDOM}$ in the water. It remains open whether increasing UVR/PAR ratios would affect the phytoplankton differently in the clear or turbid waters.

\section{Implications of phytoplankton sensitivity to PAR under increasing UVR/PAR ratios}

Despite the difficulty to precisely predict the future UVR regime in the aquatic environment $[6,46]$, there are several hints that phytoplankton might be exposed to more elevated UVR levels in the future, in clear and CDOMrich waters. Thus, by the reaction of phytoplankton to the PAR level alone, detrimental effects on cell or community level by enhanced UV radiation [8-10] may be plausible. Furthermore, the different reactions of zooplankton (to UVR) and phytoplankton (to PAR) to the light climate could lead to a de-coupling of the trophic interactions at the base of the pelagic food chain. Hence, the discovery of the reaction of phytoplankton to PAR is crucial, since this behaviour along with enhanced UVR levels, might have wide ecological implications beyond the level of primary producers. It might affect the delicate balance of trophic relations that represent an important ecosystem function of aquatic habitats with high socio-economic impact.

\section{Conclusions}

The reports on a continuous decrease in ozone and a subsequent shift in the UVR/PAR ratio are of concern since UVR effects have been shown to be detrimental to phytoplankton with possible implications on higher trophic levels of the pelagic food chain. The present paper concerns a possible avoidance strategy of phytoplankton: vertical migration in dependence of the incident solar irradiance in natural waters of two study sites (open marine, brackish).

An illumination period of about 40 min was sufficient to induce clear vertical movements of phytoplankton. The development of chlorophyll $a$ maxima could be observed in situ at both study sites, independent of the prevailing concentrations of coloured dissolved organic matter (cDOM). Vertical migration of phytoplankton was triggered by the irradiance in the 400 to $700 \mathrm{~nm}$ wavelength range (photosynthetic active radiation, PAR) at the particular water depth. In contrast, there was no clear correlation between the chlorophyll $a$ maximum depth and the intensity of the UVR range, irrespective of the PAR/UVR ratios and the surface UVR conditions. Considering the predicted increase in UV radiation and a consequent shift in the UVR/PAR ratios within the aquatic habitat, this may have consequences for the health and metabolic activity of the primary producers to impact their functionality. The implication of these findings should be pursued by further investigations of UVR effects on the aquatic assemblages with special regards to their ecosystem functionality.

\section{Materials and methods Study sites Helgoland/North Sea}

Measurements were performed in the Helgoland Harbour at the end of the south-mole, where the water column had a maximum depth of around $9 \mathrm{~m}$. The wide opening of the harbour and the large tidal amplitudes result in a continuous exchange of the water bodies with the adjacent open sea with no impact from 
effluents from the nearby island. During the campaign in spring (4 days of measurement in April/May), the weather conditions were favourable for vertical migration (temperature and salinities given in Table 1). Thermal stratification at around $1 \mathrm{~m}$ depth (difference in vertical temperature profiles measured at least during two subsequent samplings) evolved on the last 3 days; while fog in the morning and wind in the afternoon prevented stratification only on the first day. This allowed different weather scenarios to be tested with respect to phytoplankton migration.

\section{Hiddensee/Baltic Sea}

Measurements took place at the near-shore region northeast of the island Hiddensee (Libben, position $54^{\circ}$ $36^{\prime}$ and $13^{\circ} 11^{\prime}$ ) using a research vessel ("Prof. Fritz Gessner"). During the campaign in autumn (4 days of measurement in September/October), the vertical profiles of temperature (difference $<0.5^{\circ} \mathrm{C}$ ) and salinity (continuously 7.7 practical salinity units (psu) except on the last day with an inflow resulting in $8.0 \mathrm{psu}$ ) showed little variations (Table 1 ), thus indicating a well mixed water column of $5.5 \mathrm{~m}$ depth at the sampling station. During the first 2 days, strong northwest winds (up to $14 \mathrm{~m} \mathrm{~s}^{-1}$ ) induced Langmuir circulation, while on the third day the upcoming southwest wind was comparatively low (5 $\mathrm{m} \mathrm{s}^{-1}$ ) with the fourth day being almost calm. Clear sky conditions evolved in the afternoons of the days 2 and 4 ; but in the morning and on the other days dull weather prevailed resulting in an heterogeneous set of weather conditions like in the Helgoland campaign before.

\section{Irradiance measurements}

Scalar underwater irradiance was measured with a highresolution spectroradiometer (SR-9910, Macam Photometrics Ltd. Livingston, Scotland) equipped with a $10-\mathrm{m}$ light guide and a spherical light collector of $0.7 \mathrm{~cm}$ diameter. Successive underwater scans at depth intervals between 5 and $50 \mathrm{~cm}$ down to a maximum depth of 3 $m$ were done around noon and used to calculate the diffuse spectral attenuation coefficients, $K_{\mathrm{o}}(\lambda)$ (Smith, 1968). Thereby, each underwater scan took less than 2 min plus 1 min to adjust to the next depth. To determine surface irradiances, the spectroradiometer was connected to a cosine-corrected light collector and the full spectra (250 to $800 \mathrm{~nm}$ ) was recorded in spectral sampling intervals of $2 \mathrm{~nm}$ every 5 min between 4 a.m. and 10 p.m. For the time intervals $(<2 \mathrm{~h})$ when the spectroradiometer was used for underwater scans, the incident irradiance had to be interpolated with the help of a parallel running cosine-corrected PAR sensor (Li193SA, LiCor Inc., Lincoln, NE, USA) measuring surface irradiance continuously. For 2 days of the spring campaign, the spectroradiometer was not available. For these days, all PAR values refer to these LiCor readings, while UVR values were provided by the field station Zingst from ELDONET-readings [47], calibrated versus the above described spectroradiometer. The distance between the sampling site around Hiddensee and coastal field station Zingst is about $30 \mathrm{~km}$.

All optical components of the spectroradiometer are made from high-grade quartz or Teflon to allow measurements at wavelengths from 250 to $800 \mathrm{~nm}$ in 2-nm intervals. Spectral irradiance/doses measurements are presented in quantametric units (micromoles of photons per metre squared per second, PAR)/energetic units (kilojoules per metre squared, UVR), respectively. Calibration of absolute sensitivity and wavelength accuracy were performed at regular intervals against voltage-stabilised deuterium and tungsten standard lamps (Macam SR-990) traceable to the National Physical Laboratory, London, UK.

Surface irradiance and attenuation values within the water column were used to determine the underwater irradiance at the mean depth of the respective chlorophyll maxima. Thereby, the spectral data did not show any signs of irregularities that could be related to a thermocline. The thermocline evolved during the first 3 days at Helgoland long after the chlorophyll peak formation to disappear at each day in the late afternoon. For the analysis of the irradiance dependency of the formation of chlorophyll maxima, the mean value of surface irradiance was calculated for an integration period of $45 \mathrm{~min}$ prior to the chlorophyll depth profiling.

\section{Depth profiles of phytoplankton}

Vertical distribution of chlorophyll $a$ within the water column was determined fluorometrically in $0.5 \mathrm{~m}$ depth intervals by means of a "Backscat" in situ fluorometer (Haardt, Germany) taking five parallel measurements at each depth. These vertical chlorophyll $a$ profiles were recorded on an hourly basis from sunrise (5 a.m.) to sunset (9 p.m.). For calibration, the chlorophyll concentrations were determined photometrical in water samples from the corresponding water depths of the fluorometric profile, at least once a day. For this purpose, 20 to $50 \mathrm{l}$ of water was pumped up from each depth. Parts of these samples were directly investigated for their phytoplankton composition performing life counts under the light microscope in Bogorov counting chambers to distinguish between the main groups and to identify the proportion of motile phytoplankton. More samples were fixed in Lugol solution for subsequent determination in sedimentation chambers using Utermöhl technique while others were fixed in glutaraldehyde to account for picoplankton under the epifluorescence microscope. The main part of the water samples was filtered to concentrate the phytoplankton 
onto GF92 (GF/F) - filters (Schleicher and Schuell, Dassel, Germany). To extract the pigments from the filters, the residuals on the filter were kept in $5 \mathrm{ml} \mathrm{N}, \mathrm{N}$ dimethylformamide (DMF, Sigma, Germany) for $12 \mathrm{~h}$ in darkness at $4^{\circ} \mathrm{C}$. Chlorophyll concentrations were calculated by the absorbance spectra of the extract at 647 and $663 \mathrm{~nm}$, using the formula and extinction coefficients given in Porra et al. [48]. These chlorophyll concentration data served additionally to rule out potential variations of the data due to non-photochemical quenching in surface layers (see below). TC3D software (Jandel Scientific, San Rafael, CA, USA) was used to calculate the surface grid models of the spatial-temporal chlorophyll distribution by means of Gaussian equations.

\section{Photosynthesis measurements}

Photosynthetic parameters of the phytoplankton were derived in situ in dependence of the surrounding light regime using a submersible pulse-amplitude-modulated chlorophyll fluorometer (Diving-PAM, Walz GmbH, Effeltrich, Germany). Since the Diving-PAM was originally introduced for macrophytes, its application in waters with low chlorophyll content (e.g. Helgoland) would not be suitable. Thus, the instrument was used without fibre optic to get a sufficient signal to noise ratio, even with low phytoplankton densities. This resulted in an undefined penetration depth of the measuring light as well as for the fluorescence signal received, both increasing the raw signal to sufficient values of about 100 arbitrary units for Fs ("steady state fluorescence").

According to [49], the quantum yield of PSII (Genty factor, efficiency of the photochemical energy conversion) is determined in dark-adapted and light-adapted phytoplankton to calculate the theoretical maximum efficiency $(\mathrm{Fv} / \mathrm{Fm})$ and the efficiency at a particular light level $\left(\mathrm{Fv}^{\prime} / \mathrm{Fm}^{\prime}\right)$, respectively. These photon utilisation efficiency parameters served to calculate the rETR with the help of the quantum flux density of PAR. The measurements took place in the early morning before sunrise (completed before 5:15 a.m.; thus the algae have been dark-adapted over night). Using the Diving-PAM, the phytoplankton was exposed to a series of seven increasing irradiances between 15 and $700 \mu \mathrm{mol}$ photons $\mathrm{m}^{-2} \mathrm{~s}^{-1}$ (total duration $15 \mathrm{~min}$ ); the quantum yield of PSII was determined before the start of the illumination series and after each illumination period (duration 2 min each). During day time and clear sky conditions, photon utilisation efficiency parameters determined by the Diving-PAM in surface waters were used to test whether NPQ (summarising all mechanisms diminishing Fm) may explain reductions in the fluorescence signal of the "Backscat" in situ fluorometer
$[45,50]$. No such NPQ effects have been observed (data not shown).

\section{Acknowledgements}

The investigations presented here were part of the project "UV MAOR" (UV effects on marine organisms) funded by the German Federal Ministry of Education and Research (BMBF). The authors would like to thank the crew of the research vessel "Fritz Gessner" for supporting our investigations around the waters of Hiddensee. We are also grateful for the provided laboratories at the Institute of Ecology/University Greifswald and at the "Biologische Anstalt Helgoland"/Alfred-Wegener Institute für Polar- und Meeresforschung, Germany.

\section{Author details}

${ }^{1}$ Institute of Hydraulic Engineering, Hydraulic Laboratory, Pfaffenwaldring 61, University of Stuttgart, 70569 Stuttgart, Germany ${ }^{2}$ Institute of Biosciences, Aquatic Ecology, Albert-Einstein Street 3, University of Rostock, 18051 Rostock, Germany

\section{Authors' contributions}

SUG performed the field work and samples analysis, participated in data evaluation and wrote the manuscript. HRS conceived the study design, coordinated and participated in the field campaigns, contributed significantly to data evaluation and helped to draft the manuscript. All authors read and approved the final manuscript.

\section{Competing interests}

The authors declare that they have no competing interests.

Received: 3 August 2011 Accepted: 25 November 2011 Published: 25 November 2011

\section{References}

1. Solomon S: Stratospheric ozone depletion: a review of concepts and history. Rev Geophys 1999, 37:275-316.

2. Rex M, Salawitch RJ, von der Gathen P, Harris NRP, Chipperfield MP, Naujokat B: Arctic ozone loss and climate change. Geophys Res Lett 2004 31.

3. Bjorn LO, Callaghan TV, Gehrke C, Johanson U, Sonesson M, GwynnJones D: The problem of ozone depletion in northern Europe. Ambio 1998, 27:275-279.

4. Keil M, Jackson DR, Hort MC: The January 2006 low ozone event over the UK. Atmos Chem Phys Discuss 2007, 7:961-972

5. Zerefos CS, Balis DS, Bais AF, Gillotay D, Simon PC, Mayer B, Seckmeyer G: Variability of UV-B at four stations in Europe. Geophys Res Lett 1997, 24:1363-1366.

6. Mc Connell JC, Jin JJ: Stratospheric ozone chemistry. Atmosphere-Ocean 2008, 46:69-92

7. Rasch PJ, Tilmes S, Turco RP, Robock A, Oman L, Chen CC, Stenchikov GL, Garcia RR: An overview of geoengineering of climate using stratospheric sulphate aerosols. Phil Trans Math Phys Eng Sci 2008, 366:4007-4037.

8. Helbling EW, Barbieri ES, Marcoval MA, Goncalves RJ, Villafane VE: Impact of solar ultraviolet radiation on marine phytoplankton of Patagonia, Argentina. Photochem Photobiol 2005, 81:807-818.

9. Haeder DP, Kumar HD, Smith RC, Worrest RC: Effects of solar UV radiation on aquatic ecosystems and interactions with climate change. Photochemical and Photobiological Sciences 2007, 6:267-285.

10. Marinone MC, Marque SM, Suarez DA, Dieguez MDC, Perez P, Rios PDL, Soto D, Zagarese HE: UV radiation as a potential driving force for zooplankton community structure in Patagonian lakes. Photochem Photobiol 2006, 82:962-971.

11. Belzile C, Demers S, Ferreyra GA, Schloss I, Nozais C, Lacoste K, Mostajir B, Roy S, Gosselin M, Pelletier E, Gianesella SMF, Vernet M: UV effects on marine planktonic food webs: A synthesis of results from mesocosm studies. Photochem Photobiol 2006, 82:850-856.

12. De Lange HJ, Lurling M: Effects of UV-B irradiated algae on zooplankton grazing. Hydrobiologia 2003, 491:133-144. 
13. Joint I, Jordan MB: Effect of short-term exposure to UVA and UVB on potential phytoplankton production in UK coastal waters. J Plankton Res 2008, 30:199-210.

14. Liang $Y$, Beardall J, Heraud P: Effect of UV radiation on growth, chlorophyll fluorescence and fatty acid composition of Phaeodactylum tricornutum and Chaetoceros muelleri (Bacillariophyceae). Phycologia 2006, 45:605-615.

15. Reichwaldt ES, Stibor $H$ : The impact of diel vertical migration of Daphnia on phytoplankton dynamics. Oecologia 2005, 146:50-56.

16. Ringelberg J: The photobehaviour of Daphnia spp. as a model to explain diel vertical migration in zooplankton. Biol Rev 1999, 74:397-423.

17. Haeder D: Ultraviolet radiation and aquatic microbial ecosystems. In Ecosystems, evolution and ultraviolet radiation. Edited by: Cockell C, Blaustein A. New York: Springer; 2001:150-169.

18. Iseki M, Matsunaga S, Murakami A, Ohno K, Shiga K, Yoshida K, Sugai M, Takahashi T, Hori T, Watanabe M: A blue-light-activated adenylyl cyclase mediates photoavoidance in Euglena gracilis. Nature 2002, 415:1047-1051.

19. Gliwicz MZ: Predation and the evolution of vertical migration in zooplankton. Nature 1986, 320:746-748.

20. Stich HB, Lampert W: Predator evasion as an explanation of diurnal vertical migration by zooplankton. Nature 1981, 293:396-398.

21. Barbieri ES, Villafane VE, Helbling EW: Experimental assessment of UV effects on temperate marine phytoplankton when exposed to variable radiation regimes. Limnol Oceanogr 2002, 47:1648-1655.

22. Marcoval MA, Villafane VE, Helbling EW: Interactive effects of ultraviolet radiation and nutrient addition on growth and photosynthesis performance of four species of marine phytoplankton. J Photochem Photobiol B Biol 2007, 89:78-87.

23. Richter PR, Hader DP, Goncalves RJ, Marcoval MA, Villafane VE, Helbling EW: Vertical migration and motility responses in three marine phytoplankton species exposed to solar radiation. Photochem Photobiol 2007, 83(4):810-817.

24. Zepp RG, Callaghan TV, Erickson DJ: Interactive effects of ozone depletion and climate change on biogeochemical cycles. Photochemical and Photobiological Sciences 2003, 2:51-61.

25. Morris DP, Zagarese $H$, Williamson CE, Balseiro EG, Hargreaves BR, Modenutti B, Moeller R, Queimalinos C: The attentuation of solar UV radiation in lakes and the role of dissolved organic carbon. Limnol Oceanogr 1995, 40:1381-1391.

26. Jerlov NG: Marine Optics Amsterdam: Elsevier; 1976

27. Reinart A, Herlevi A: Diffuse attenuation coefficient in some Estonian and Finnish lakes. Proc Estonian Acad Sci Biol Ecol 1999, 48:267-283.

28. Schubert H, Sagert S, Forster RM: Evaluation of the different levels of variability in the underwater light field of a shallow estuary. Helgoland Marine Research 2001, 55:12-22.

29. Domin A, Schubert $H$, Krause JC, Schiewer U: Modelling of pristine depth limits for macrophyte growth in the southern Baltic Sea. Hydrobiologia 2004, 514:29-39.

30. Walsby AE: Numerical integration of phytoplankton photosynthesis through time and depth in a water column. New Phytologist 1997, 136:189-209.

31. Gerbersdorf SU, Meyercordt J, Meyer-Reil LA: Microphytobenthic primary production in the Bodden estuaries, southern Baltic Sea, at two study sites differing in trophic status. Aquat Microb Ecol 2005, 41:181-198.

32. Wasmund N, Uhlig S: Phytoplankton trends in the Baltic Sea. Ices Journal of Marine Science 2003, 60:177-186.

33. Sagert $\mathrm{S}$, Rieling $\mathrm{T}$, Eggert $\mathrm{A}$, Schubert $\mathrm{H}$ : Development of a phytoplankton indicator system for the ecological assessment of brackish coastal waters (German Baltic Sea coast). Hydobiologia 2008, 611:91-103.

34. Niell FX: Adaptation to light of organisms that cause red tide ecophysiological reflection. In Conf on Red Tides as a Natural Phenomenon. Edited by: Fraga FFF. Jul; Corunna, Spain; 1987:55-61.

35. Haeder DP: Ecological consequences of photomovement in microorganisms. J Photochem Photobiol B Biol 1988, 1:385-414.

36. Kelly-Gerreyn BA, Anderson TR, Holt JT, Gowen RJ, Proctor R: Phytoplankton community structure at contrasting sites in the Irish Sea: a modelling investigation. Estuar Coast Shelf Sci 2004, 59:363-383.

37. Hoppenrath M: A revised checklist of planktonic diatoms and dinoflagellates from Helgoland (North Sea, German Bight). Helgoland Marine Research 2004, 58:243-251.
38. Wasmund N, Gobel J, Von Bodungen B: 100-years-changes in the phytoplankton community of Kiel Bight (Baltic Sea). J Mar Syst 2008, 73:300-322.

39. Haeder DP: Novel method to determine vertical distributions of phytoplankton in marine water columns. Environ Exp Bot 1995, 35:547-555.

40. Figueroa FL, Niell FX, Figueiras FG, Villarino ML: Diel migration of phytoplankton and spectral light field in the Ria de Vigo (NW Spain). Mar Biol 1998, 130:491-499.

41. Rhode SC, Pawlowski M, Tollrian R: The impact of ultraviolet radiation on the vertical distribution of zooplankton of the genus Daphnia. Nature 2001, 412:69-72.

42. Galland P, Keiner P, Dornemann D, Senger H, Brodhun B, Hader DP: Pterinlike and Flavin-like fluorescence associated with isolated flagella of Euglena gracilis. Photochem Photobiol 1990, 51:675-680.

43. Kaczmarska I, Clair TA, Ehrman JM, MacDonald SL, Lean D, Day KE: The effect of ultraviolet $B$ on phytoplankton populations in clear and brown temperate Canadian lakes. Limnol Oceanogr 2000, 45:651-663.

44. Vernet M: Effects of UV radiation on the physiology and ecology of marine phytoplankton. In The Effects of UV Radiation in the Marine Environment. Edited by: de Mora S, Demers S, Vernet M. Cambridge: Cambridge University Press; 2000:237-278.

45. Schubert H, Forster RM, Schoor A, Ockenfeld K: Horizontale und vertikale Chlorophyllverteilung des Bodstedter Boddens. Rostocker Meeresbiologische Beiträge 1997, 5:69-83.

46. Roy S, Mohovic B, Gianesella SMF, Schloss I, Ferrario M, Demers S: Effects of enhanced UV-B on pigment-based phytoplankton biomass and composition of mesocosm-enclosed natural marine communities from three latitudes. Photochem Photobiol 2006, 82:909-922.

47. Haeder D-P, Lebert M, Marangoni R, Colombetti G: ELDONET: European Light Dosimeter Network hardware and software. J Photochem Photobiol B Biol 1999, 52:51-58.

48. Porra RJ, Thompson WA, Kriedemann PE: Determination of accurate extinction coefficients and simultaneaous equations for assaying chlorophylls $\mathrm{a}$ and $\mathrm{b}$ extracted with four different solvents: verification of the concentration of chlorophyll standards by atomic absorption spectroscopy. Biochim Biophys Acta 1989, 975:384-394.

49. Genty B, Briantais JM, Baker NR: The relationship between the quantum yield of photosynthetic electron transport and quenching of chlorophyll fluorescence. Biochim Biophys Acta 1989, 990:87-92.

50. Krause GH, Vernotte C, Briantais JM: Photoinduced quenching of chlorophyll fluorescence in intact chloroplasts and algae. Resolution into two components. Biochim Biophys Acta 1982, 679:116-124.

doi:10.1186/2190-4715-23-36

Cite this article as: Gerbersdorf and Schubert: Vertical migration of phytoplankton in coastal waters with different UVR transparency. Environmental Sciences Europe 2011 23:36.

\section{Submit your manuscript to a SpringerOpen ${ }^{\odot}$ journal and benefit from:}

- Convenient online submission

- Rigorous peer review

- Immediate publication on acceptance

- Open access: articles freely available online

- High visibility within the field

- Retaining the copyright to your article

Submit your next manuscript at $>$ springeropen.com 